\title{
Social Media Cost and the Levels of Cash Flow Among Listed Banks in Emerging Economies in Africa
}

\author{
Olaoluwa Elsie Umukoro ${ }^{1}$, Olubukunola Ranti Uwuigbe ${ }^{1}$, Imoleayo Obigbemi ${ }^{1}$ \& Uwalomwa Uwuigbe ${ }^{1}$ \\ ${ }^{1}$ Covenant University, Nigeria \\ Correspondence: Olaoluwa Elsie Umukoro, Covenant University, Nigeria.
}

Received: December 22, 2019

Accepted: March 2, 2020

Online Published: July 7, 2020

doi:10.5430/ijfr.v11n4p370

URL: https://doi.org/10.5430/ijfr.v11n4p370

\begin{abstract}
We examine the effect of social media advertising on the operating, financing and investing level of cash flow based on listed banks in emerging economies in Africa. We employ control variables such as board size and financial leverage to control other factors not captured in our model. Results obtained reveal that social media costs aid all levels of cash flow in Ghana and South-Africa. Social media costs in Botswana have a significant impact with operating and financing cash flow and an insignificant effect with investing cash flow. The results obtained from Kenya revealed a significant relationship between the independent variable and the financing and investing cash flow while an insignificant relationship was statistically obtained when social media cost was regressed against the operating level of cash flow. The Tanzanian results reveal a significant impact with the financing and investing level of cash flow but an insignificant value was obtained from the operating level of cash flow. The Nigerian results yielded an insignificant value, from the operating and financing level of cash flow, while investing cash flow generated a significant relationship.
\end{abstract}

Keywords: social media cost, cash flow, financial leverage, emerging economies

\section{Introduction}

\subsection{Statement of Problem}

Social media cost simply means the media and advertising cost borne by the organisation. The advertising strategy is basically the use of social platforms and the media be it print, visual and radio to publicise their services, goods and products (Unachukwu, 2004; Ikpefan, 2013 \& Joyce, 2018). The use of social media has become an important tool in promoting businesses and brands. A lot of social media influencers have emerged in recent times and are seen promoting various brands using different social media sites. Various listed banks in Nigeria and outside Nigeria sponsor various television and radio programmes, they also have very catchy, 'sing along' adverts, all with the aim of the increasing profits and customer base. Despite all these efforts, various listed banks in Africa have collapsed or had to merge due to the inability to fulfil her going concern objective. Hence the main aim of this study is to determine if social media cost influences any of the three levels of cash flow of listed banks in emerging economies in Africa?

\subsection{Literature Review}

Listed banks such as First National Bank, Zenith Bank Africa, African Bank, Bank of Kenya, Guarantee Trust Bank, Skye Bank, Union Bank and First Bank engage in various forms of advertisements, both on print and social media and this is channelled to increasing publicity and revenue. Guarantee Trust bank is the sole sponsor of Ndani Online Tv, Fidelity bank sponsored King of boys, Access bank sponsored Tinsel, United Bank of Africa is the head line sponsor of the 'the Mens club' web series in on RedTv, First City Monument Bank (FCMB) sponsors the literacy TV show etc. Various organisations and Institutions sponsor 'Big Brother Nigeria and Africa' show and this is to increase their publicity. They expend a lot of cash by pushing out content that would portray their brand in a good light and increase publicity with the hope that the various forms of advertisements engaged in would yield increase in cash, customers and goodwill. Uyiar, Boyar, \& Kuzey (2018) concluded that social media has a significant positive effect on firm value.

Okari (2017) empirically determined the effect of social media usage on the financial performance of microfinance institutions in Kenya. The study utilized both primary and secondary data. The Anova tool was used in measuring 
both dependent and independent variables, similar studies employ the use of more research enabled statistic tools. The study did not measure how the usage of social media influences cash inflows, investing and financing decision. The study is also limited to Kenya hence generalization of the results might not be possible. The financial statements analyzed in this study captured only three years (2014-2016).

The study delved into social media sentiment and financial performance, it employed the portfolio method of examining if organizations that have high or low social media comments actually have higher or lower returns or abnormal returns, the period measured was limited to two years, as a daily stock and returns for those two years were measured. This time frame is not sufficient enough to make a generalized conclusion (Tamrakar, 2016). The study delved into if social media comments influence an organization cash flow, only cash flow figures from operating activities of the firms were considered in this research, other cash flow figures were not subjected to testing. The study made use of time series method on analysis because it considered only quarters from the year 2012- 2015 and this is not sufficient to draw general conclusions. The study population is limited to the United States of America (Tamrakar, 2016).

Unachukwu (2004) examined the usefulness of strategic marketing in the Nigerian deposit money banks. The study's objectives failed to examine social media as one of the tools of strategic marketing that listed banks now employ, the study was limited to the use of primary data and only three Nigerian banks were captured in the study. Ikpefan (2013) examines the effect of marketing on the services and products in listed banks in Nigeria. The study failed to analyse the various marketing options listed banks make use of while advertising their products, the study made use of primary data which is limited to the distribution of questionnaire. The study made use of the T-test method which holistically tests all variables involved in the study. Conclusively, World Bank Group (2017) analysed the digital markets and how listed banks, it was established the financial institutions should employ the use of technology and marketing skills in other to continue to reduce the unbanked population, the study however, failed to examine how the use of technology and marketing thus far has helped increase or reduce cash flow, the study was an exploratory research.

Listed banks are in constant competition to release trendy and innovative adverts that would get them trending, more instances can be seen in telecommunications and other industries. The question here then is how much money does 'corporate strategies' bring back to listed banks or organisations? Does the continuous use of social media increase the amount of money earned by listed banks or organisations? Print media has listed some organisations, listed banks and institutions in time past that have engaged in social media advertising and yet still folded up, while some are still in active business. This study seeks to examine empirically if the use of social media and content creation explored by listed banks have an effect on the amount of cash earned in any given financial year in Emerging Economies in Africa.

The extensive use of social media adverts has become the status quo. Joyce (2018) has stated that listed banks in advanced countries are reaping the benefits of increased adverts through increase in revenue. Although print media have recorded several listed banks that invested heavily in adverts and are no longer in operation due to inability to fulfil their financial obligations while some are still in existence.

\subsection{Research Hypothesis}

It is against this backdrop that the study tested the following hypotheses:

i. There is no significant relationship between social media cost and the operating level of cash flow.

ii. There is no significant impact between social media cost and the financing level of cash flow.

iii. There is no significant relationship between social media cost and the investing level of cash flow.

\section{Methodology}

The researcher made use of the expo-facto research design subjecting the dependent and independent variables to a panel data regression analysis. Secondary data was used to empirically validate this work as data would be collated from the financial statements of the selected listed banks. STATA software tool was utilized.

\subsection{Population}

The Population of this study consists of all listed banks in Emerging Economies in Africa 2019, (IMF, 2019: Africa business, 2019) (IMF 2019). South-Africa was added to the sample size of this study because it is the only African country ranked among the BRICS emerging economies in the world (BRICS, 2019).

The study narrowed its sample size to include emerging economies only because emerging markets/economies are 
economies that are moving away from the traditional methods of funding their economies. They adapt various strategies that aid increase in cash flow, visibility, financial stability and global relevance. IMF 2019 and BRICS 2019 have stated African countries that fall in this category and this study utilized data from countries whose financial statements were audited, published and available from the year 2013-2018.

\subsection{Sample Size}

The countries selected include Ghana, Nigeria, South-Africa, Botswana, Kenya and Tanzania. The countries were selected based on the availability of the financial statements for the time frame (2013-2018) of the study. Financial statements of some listed banks in Emerging Economies in Africa between the years 2013-2018 were not available for public consumption and research purposes, hence their exclusion from the sample size. This study employs data from only listed banks in these regions majorly because the Stock Exchange Markets are regulated and data obtained from there have at least been validated by external auditors. A total of thirty-eight listed banks in Africa have been selected as the Sample size. The regression analysis applied the robust formula during the statistical analysis.

\subsection{Research Design}

This study adopted the expo-facto research design. Financial statements of listed banks were utilized for the study.

\subsection{Research Models}

$$
\begin{aligned}
& \text { OPCF }=\beta_{0}+\beta_{1} \mathrm{SMC}_{i t}+\beta_{2} \mathrm{BS}_{i t}+\beta_{3} \mathrm{FL}_{\mathrm{it}}+\beta_{4} \mathrm{BC}_{\mathrm{it}}+\mathrm{U}_{\mathrm{it}} \\
& \text { FINCF }=\beta_{0}+\beta_{1} \mathrm{SMC}_{\mathrm{it}}+\beta_{2} \mathrm{BS}_{\mathrm{it}}+\beta_{3} \mathrm{FL}_{\mathrm{it}}+\beta_{4} \mathrm{BC}_{\mathrm{it}}+\mathrm{U}_{\mathrm{it}} \\
& \mathrm{INVCF}=\beta_{0}+\beta_{1} \mathrm{SMC}_{\mathrm{it}}+\beta_{2} \mathrm{BS}_{\mathrm{it}}+\beta_{3} \mathrm{FL}_{\mathrm{it}}+\beta_{4} \mathrm{BC}_{\mathrm{it}}+\mathrm{U}_{\mathrm{it}}
\end{aligned}
$$

Model 3

Where:

$\beta_{0}$ is the intercept

$\beta_{1-4}$ is the coefficients of the explanatory variables

$\mathrm{U}_{\mathrm{it}}$ is the error or disturbing term that absorb the influence of omitted variables in proxies used.

\section{Regression Results}

Table 1. Regression table for hypothesis one (A) (Ghana)

\begin{tabular}{lllll}
\hline Operating cash flow & Coefficient & Standard error & T & Probability \\
\hline Social Media Cost & 12.93577 & 3.89396 & 3.32 & 0.003 \\
\hline Board Size & 2.378546 & 8.348614 & 0.28 & 0.778 \\
\hline Leverage & 1.483724 & 3.245007 & 0.46 & 0.652 \\
\hline
\end{tabular}

Prob $>$ F $=0.00261$ (Fixed Result).

Source: Author's Computation (2019).

\section{Decision}

Accept Alternate: There is a significant relationship between social media cost and the operating level of cash flow of listed banks in Ghana. The result is significant because the Probability value obtained from the regression is less than $5 \%$.

Table 2. Regression table for hypothesis one (B)

\begin{tabular}{lllll}
\hline Financing cash flow & Coefficient & Standard error & T & Probability \\
\hline Social Media cost & 2.382057 & .897547 & 2.65 & 0.008 \\
\hline Board size & .8507915 & 4.046862 & 0.21 & 0.833 \\
\hline Leverage & .774049 & 2.286886 & 0.03 & 0.973
\end{tabular}

Prob $>\mathrm{F}=0.0244$ (Random Result).

Source: Author's Computation, (2019). 
Decision

Accept Alternate: There is a significant relationship between social media cost and the financing level of cash flow of listed banks in Ghana. The result is significant because the Probability value obtained from the regression is less than 5\%.

Table 3. Regression table for hypothesis one (C)

\begin{tabular}{lllll}
\hline Investing cash flow & Coefficient & Standard error & T & Probability \\
\hline Social Media Cost & 28.16815 & 4.805743 & 5.86 & 0.000 \\
\hline Board Size & -7.824068 & 21.66815 & -0.36 & 0.718 \\
\hline Leverage & -.9776509 & 12.24469 & -0.08 & 0.936 \\
\hline
\end{tabular}

Prob $>\mathrm{F}=0.0497$ (Random Result).

Source: Author's Computation, (2019).

\section{Decision}

Accept Alternate: There is a significant relationship between social media cost and the investing level of cash flow of listed banks in Ghana. The result is significant because the Probability value obtained from the regression is less than $5 \%$.

Table 4. Regression table for hypothesis one (A) (Nigeria)

\begin{tabular}{lllll}
\hline Operating cash flow & Coefficient & Standard errors & T & Probability \\
\hline Social Media Cost & -.3731312 & 0.6010564 & -0.62 & 0.537 \\
\hline Board Size & 2.212396 & 1.900562 & 1.16 & 0.249 \\
\hline Leverage & 0.159408 & 0.512083 & 0.31 & 0.757 \\
\hline
\end{tabular}

Prob $>\mathrm{F}=0.02$ (Fixed Result).

Source: Authors Computation (2019)

Decision

Accept null hypothesis: There is no significant relationship between Social Media cost and the operating level of cash flow of listed banks in Nigeria. The result is insignificant because the Probability value obtained from the regression is more than $5 \%$.

Table 5. Regression table for hypothesis one (B) (Nigeria)

\begin{tabular}{lllll}
\hline Financial cash flow & Coefficient & Standard Error & T & Probability \\
\hline Social Media cost & -0.0533354 & .1244187 & -0.43 & 0.668 \\
\hline Board Size & -.4807064 & .3184353 & -1.51 & 0.131 \\
\hline Leverage & .0904193 & .1062075 & 0.85 & 0.395 \\
\hline
\end{tabular}

Prob $>\mathrm{F}=0.02$ (Fixed Result).

Source: Author's Computation (2019).

\section{Decision}

Accept null hypothesis: There is no significant relationship between Social Media cost and the financing level of cash flow of listed banks in Nigeria. The result is insignificant because the Probability value obtained from the regression is more than $5 \%$. 
Table 6. Regression table for hypothesis one (C) (Nigeria)

\begin{tabular}{lllll}
\hline Investing cash flow & Coefficient & Standard Error & T & Probability \\
\hline Social Media Cost & 9.028467 & 3.985823 & 2.27 & 0.027 \\
\hline Board Size & -13.301 & 12.60331 & -1.06 & 0.295 \\
\hline Leverage & .306771 & 3.395823 & 0.09 & 0.928 \\
\hline
\end{tabular}

Prob $>\mathrm{F}=0.05$ (Fixed Result).

Source: Author's Computation (2019).

\section{Decision}

Accept Alternate hypothesis: There is a significant relationship between Social Media cost and the investing level of cash flow of listed banks in Nigeria. The result is significant because the Probability value obtained from the regression is less than $5 \%$.

Table 7. Regression table for hypothesis one (A) (South-Africa)

\begin{tabular}{lllll}
\hline Operating cash flow & Coefficients & Standard errors & T & Probability \\
\hline Social Media Cost & 4.732622 & .7624235 & 6.21 & 0.000 \\
\hline Board Size & 0.0234555 & .0443574 & 0.53 & 0.597 \\
\hline Leverage & .1234151 & .0552581 & -2.23 & 0.026 \\
\hline
\end{tabular}

Prob $>\mathrm{F}=0.000$ (Fixed Result).

Source: Authors Computation (2019).

Decision

Accept alternate hypothesis: There is a relationship between social media cost and operating level of cash flow of listed banks in South-Africa. The result is significant because the Probability value obtained from the regression is less than $5 \%$.

Table 8. Regression table for hypothesis one (B) (South-Africa)

\begin{tabular}{lllll}
\hline Financing cash flow & Coefficients & Standard errors & t & Probability \\
\hline Social Media Cost & 1.423949 & .5126082 & 2.78 & 0.005 \\
\hline Board Size & .0243407 & .0197374 & 1.23 & 0.217 \\
\hline Leverage & -.0100261 & .0234446 & -0.43 & 0.669 \\
\hline
\end{tabular}

Prob $>\mathrm{F}=0.000$ (Fixed Result).

Source: Author's Computation (2019).

Decision:

Reject null hypothesis: There is no significant relationship between social media cost and financing cash flow. The result is significant because the Probability value obtained from the regression is equal to $5 \%$.

Table 9. Regression table for hypothesis one (C) (South-Africa)

\begin{tabular}{lllll}
\hline Investing cash flow & Coefficient & Standard errors & T & Probability \\
\hline Social Media cost & -15.3787 & 5.364994 & -2.87 & 0.010 \\
\hline Board size & -.2732957 & .2684034 & -1.02 & 0.321 \\
\hline Leverage & -.306871 & .494866 & -0.62 & 0.543
\end{tabular}

Prob $>\mathrm{F}=0.000$ (Fixed Result).

Source: Author's Computation (2019). 
Decision

Reject null hypothesis: There is no significant relationship between social media cost and investing cash flow. The result is significant because the Probability value obtained from the regression is less than 5\%.

Table 10. Regression table for hypothesis one (A) (Botswana)

\begin{tabular}{lllll}
\hline Operating cash flow & Coefficients & Standard errors & $\mathbf{T}$ & Probability \\
\hline Social media cost & 3.181702 & .7855182 & 4.05 & 0.000 \\
\hline Board size & 46.91605 & 69.16677 & 0.68 & 0.498 \\
\hline Leverage & 49.50569 & 42.63031 & 1.16 & 0.246 \\
\hline
\end{tabular}

Prob $>\mathrm{F}=0.000$ (Random Result).

Source: Author's computation (2019).

Decision

Reject null hypothesis: There is no significant relationship between social media cost and operating cash flow. The result is significant because the Probability value obtained from the regression is less than 5\%.

Table 11. Regression table for hypothesis one (B) (Botswana)

\begin{tabular}{lllll}
\hline Financing cash flow & Coefficients & Standard errors & T & Probability \\
\hline Social media cost & .6351249 & .0723128 & 8.78 & 0.000 \\
\hline Board size & -21.46919 & 6.347546 & -3.38 & 0.001 \\
\hline Leverage & -2.432539 & 3.433265 & -0.71 & 0.479
\end{tabular}

Prob $>\mathrm{F}=0.000$ (Random Result).

Source: Author's computation (2019).

Decision

Reject null hypothesis: There is no significant relationship between social media cost and financing cash flow. The result is significant because the Probability value obtained from the regression is less than 5\%.

Table 12. Regression table for hypothesis one (C) (Botswana)

\begin{tabular}{lllll}
\hline Investing cash flow & Coefficients & Standard errors & T & Probability \\
\hline Social Media cost & -10.80096 & 6.587262 & -1.62 & 0.101 \\
\hline Board size & 501.1912 & 514.9701 & 0.98 & 0.329 \\
\hline Leverage & -172.8128 & 120.660 & -1.43 & 0.329 \\
\hline
\end{tabular}

Prob $>\mathrm{F}=0.000$ (Random Result).

Source: Author's computation (2019).

Decision

Accept null hypothesis: There is no significant relationship between social media cost and investing cash flow. The result is insignificant because the Probability value obtained from the regression is more than 5\%. 
Table 13. Regression table for hypothesis one (A) (Kenya)

\begin{tabular}{lllll}
\hline Operating cash flow & Coefficients & Standard errors & T & Probability \\
\hline Social Media cost & -.3752877 & .617184 & -0.61 & 0.560 \\
\hline Board size & -1.898682 & 1.953461 & -0.97 & 0.360 \\
\hline Leverage & 1.963837 & .8056852 & 2.44 & 0.041 \\
\hline
\end{tabular}

Prob $>\mathrm{F}=0.1561$ (Random Result).

Source: Author's computation (2019).

Decision

Accept null hypothesis: There is no relationship between social media cost and operating cash flow. The result is insignificant because the Probability value obtained from the regression is more than 5\%.

Table 14. Regression table for hypothesis one (B) (Kenya)

\begin{tabular}{lllll}
\hline Financing cash flow & Coefficients & Standard errors & T & Probability \\
\hline Social Media cost & -.5550336 & .1022517 & -5.43 & 0.000 \\
\hline Board size & .3278212 & .177553 & 1.85 & 0.065 \\
\hline Leverage & .2927958 & .11382 & 2.57 & 0.010 \\
\hline
\end{tabular}

Prob $>\mathrm{F}=0.000$ (Random Result).

Source: Author's computation (2019).

Decision

Reject null hypothesis: There is no relationship between social media cost and operating cash flow. The result is significant because the Probability value obtained from the regression is less than 5\%.

Table 15. Regression table for hypothesis one (C) (Kenya)

\begin{tabular}{lllll}
\hline Investing cash flow & Coefficients & Standard errors & t & Probability \\
\hline Social media cost & -1.217365 & .6217809 & -1.96 & 0.086 \\
\hline Board size & -1.879742 & 1.968011 & -0.96 & 0.367 \\
\hline Leverage & -2.976224 & .8116861 & -3.67 & 0.006
\end{tabular}

Prob $>\mathrm{F}=0.000$ (Fixed Result).

Source: Author's computation (2019).

Decision

Accept null hypothesis: There is no relationship between social media cost and operating cash flow. The result is insignificant because the Probability value obtained from the regression is more than 5\%.

Table 16. Regression table for hypothesis four (A) (Tanzania)

\begin{tabular}{lllll}
\hline Operating cash flow & Coefficients & Standard errors & t & Probability \\
\hline Social Media cost & -4.155907 & 5.304242 & 0.35 & 0.726 \\
\hline Board size & -36.20172 & 7.576328 & -0.81 & 0.419 \\
\hline Leverage & -27.9855 & 2.345898 & -0.59 & 0.554 \\
\hline
\end{tabular}

Prob $>\mathrm{F}=0.0000$ (Fixed Result).

Source: Author's computation (2019). 
Decision

Accept null hypothesis: There is no relationship between social media cost and operating cash flow. The result is insignificant because the Probability value obtained from the regression is more than 5\%.

Table 17. Regression table for hypothesis four (B) (Tanzania)

\begin{tabular}{lllll}
\hline Financing cash flow & Coefficients & Standard errors & T & Probability \\
\hline Social Media cost & .0794688 & .0151113 & 5.26 & 0.006 \\
\hline Board size & -.4498921 & .0912602 & -4.93 & 0.008 \\
\hline Leverage & -.2676132 & .0266614 & -10.04 & 0.001 \\
\hline
\end{tabular}

Prob $>\mathrm{F}=0.0000$ (Fixed Result).

Source: Author's computation (2019).

Decision

Reject null hypothesis: There is no relationship between social media cost and operating cash flow. The result is significant because the Probability value obtained from the regression is less than $5 \%$.

Table 18. Regression table for hypothesis four (C) (Tanzania)

\begin{tabular}{lllll}
\hline Investing Cash flow & Coefficients & Standard errors & T & Probability \\
\hline Social Media cost & 1.206455 & .3979957 & 3.03 & 0.039 \\
\hline Board size & 13.51144 & 2.363231 & 5.72 & 0.005 \\
\hline Leverage & 10.4462 & 1.368448 & 7.63 & 0.002
\end{tabular}

Prob $>\mathrm{F}=0.0000$ (Fixed Result).

Source: Author's computation (2019).

Decision

Reject null hypothesis: There is no relationship between social media cost and operating cash flow.

Table 19. Summary table

\begin{tabular}{lllllll}
\hline & Ghana & Nigeria & South-African & Botswana & Kenya & Tanzania \\
\hline Operating cash flow & Reject null & Accept null & Reject null & Reject null & Accept null & Accept null \\
\hline Financing cash flow & Reject null & Accept null & Reject null & Reject null & Reject null & Reject null \\
\hline Investing cash flow & Reject null & Reject null & Reject null & Accept null & Accept null & Reject null \\
\hline
\end{tabular}

Source: Author's computation (2019).

\section{Discussion}

\subsection{Test of Hypothesis One $\left(H_{01}\right)$ (Ghana)}

$\mathrm{H}_{0}$ : There is no significant relationship between social media cost and the level of cash flow (operating, financing and investing) of listed banks in Ghana.

Stating hypothesis one in relation to each independent variable we have:

A. There is no significant relationship between social media cost and the operating level of cash flow of listed banks in Ghana.

B. There is no significant relationship between social media cost and the financing level of cash flow of listed 
banks in Ghana.

C. There is no significant relationship between social media cost and the investing level of cash flow of listed banks in Ghana.

\subsubsection{Discussion and Findings}

The dependent variable operating cash flow yielded a positive $P$ value of 0.003 when regressed with the independent variable social media cost. This infers that the use of social media cost would aid operating cash inflow and as an extension the financial longevity of listed banks in Ghana. The empirical table above went further to reveal that a $1 \%$ increase in social media cost would yield a $13 \%$ increase in operating cash flow. Other variables that would lead to an increase in investment cash flow were not captured in this model.

The second dependent variable for this study financing cash flow also produced a positive $\mathrm{P}$ value of 0.008 . This implies that the use of adverts as a corporate strategy has a positive significance with financing cash flow. The statistical table reveals that a $1 \%$ increase in social media cost would generate a $2.4 \%$ increase in financing cash flow. Other variables that would lead to an increase in investment cash flow were not captured in this model.

In the same vein, the third dependent variable for this study investing cash flow, generated a significant P-value of 0.000. This simply means social media cost has an effect on Investing cash flow on listed banks in Ghana. The coefficient went further to reveal a positive relationship between both variables tested. A $1 \%$ increase in social media cost resulted in a $28 \%$ increase in investing cash flow. Other variables that would lead to an increase in investment cash flow were not captured in this model.

The results obtained above are in contrast with (Tamrakar, 2016). The $\mathrm{P}$ value obtained from the tables above is in line with (Joyce, 2018), who stated that banks in developed countries employ the use of online content and adverts to boost revenue. Unachukwu (2004) also stated that the use of marketing strategies, which advertising is part of, helps boost bank operations and create awareness. Ikpefan (2013) also statistically endorsed the alternate hypothesis of his study as he recommends the continuous use of marketing as one of the strategies that leads to the acceptance and subscribing to services offered by banks. Merino, Srinivasan and Srivastava (2007) study is also in tandem with this study's findings as they statistically discover that a firms advertising plays a significant role in determination of a firm's cash flow variability. In the same vein (Okari, 2017) discovered that the use of social media has a significant relationship with financial performance in Kenya. Conclusively, Kumar, Rama and Devi (2014) established a theoretical relationship between social media and financial services.

\subsection{Test of Hypothesis One $\left(H_{01}\right)$ (Nigeria)}

$\mathrm{H}_{0}$ : There is no significant relationship between social media cost and the level of cash flow (operating, financing and investing) of listed banks in Nigeria.

Stating hypothesis one in relation to each independent variable we have:

A. There is no significant relationship between social media cost and the operating level of cash flow of listed banks in Nigeria.

B. There is no significant relationship between social media cost and the financing level of cash flow of listed banks in Nigeria.

C. There is no significant relationship between social media cost and the investing level of cash flow of listed banks in Nigeria.

\subsubsection{Discussion and Findings}

Social media cost obtained an inverse insignificant relationship with operating cash flow where listed banks in Nigeria are concerned. The coefficient value revealed -.37. This means that a $1 \%$ increase in social media cost would result in a decrease in operating cash flow. This result is at variance with prior researchers (Unachukwu, 2004; Ikpefan 2013; Tamrakar, 2016 \& Joyce, 2018) study who have recommended social media as a very important public relation tool.

In the same vein, Social media cost obtained an inverse and insignificant relationship with the second dependent variable financial cash flow. The co-efficient variable reveals that a $1 \%$ increase in social media cost would lead to -0.05 decrease in financial cash flow. This result is at variance with (Unachukwu, 2004; Ikpefan 2013; Tamrakar, 2016 \& Joyce, 2018).

The result stated above is in contrast with the results obtained from Ghana and prior studies. The result stated above reveals that in the Nigerian scenario there is an inverse relationship between social media cost and operating cash 
flow. This further explains why certain listed banks in Nigeria such as Bank Phb, Skye bank, Diamond bank, and Intercontinental bank have had to either wind up or merge due to inability fulfil financial obligations even though they engage heavily in the use of adverts.

Similarly, social media cost and investing cash flow obtained a significant and positive relationship. The coefficient result revealed a 9\% increase in investing cash flow for every $1 \%$ increase in social media cost. This result is in tandem with prior authors such as (Unachukwu, 2004; Ikpefan 2013; Tamrakar, 2016 \& Joyce, 2018).

\subsection{Test of Hypothesis One $\left(H_{01}\right)$ (South-Africa)}

$\mathrm{H}_{0}$ : There is no significant relationship between social media cost and the level of cash flow (operating, financing and investing) of listed banks in South-Africa.

Stating hypothesis one in relation to each independent variable we have:

A. There is no significant relationship between social media cost and the operating level of cash flow of listed banks in South-Africa.

B. There is no significant relationship between social media cost and the financing level of cash flow of listed banks in South-Africa.

C. There is no significant relationship between social media cost and the investing level of cash flow of listed banks in South-Africa

\subsubsection{Discussion and Findings}

Social media cost obtained a positive significant relationship with operating cash flow where listed banks in South-Africa are concerned (P-value). The coefficient value revealed 5\%. This means that a $1 \%$ increase in social media cost would result in a 5\% increase in operating cash flow. This result is at par with prior researchers (Unachukwu, 2004; Ikpefan 2013; Tamrakar, 2016 \& Joyce, 2018) study who have recommended social media as an important tool for global advancement and revenue generation. This result is at variance with that obtained from the Nigerian sample size.

In the same vein, social media cost obtained a positive and significant relationship with the second dependent variable financial cash flow. The co-efficient variable reveals that a $1 \%$ increase in social media cost would lead to 1.4 increase in financial cash flow. This result obtained is in line with prior studies (Unachukwu, 2004; Ikpefan 2013; Tamrakar, 2016 \& Joyce, 2018).

Conclusively, social media cost and investing cash flow obtained a significant $(P=0.000)$ and inverse relationship. The coefficient result revealed a $-15 \%$ increase in investing cash flow for every $1 \%$ increase in social media cost. This result is in tandem with the statistical evidence obtained from Ghana and prior authors such as (Unachukwu, 2004; Ikpefan 2013; Tamrakar, 2016 \& Joyce, 2018).

\subsection{Test of Hypothesis One $\left(H_{01}\right)$ (Botswana)}

$\mathrm{H}_{0}$ : There is no significant relationship between Social media cost and the level of cash flow (operating, financing and investing) of listed banks in Botswana.

Stating hypothesis one in relation to each independent variable we have:

A. There is no significant relationship between Social media cost and the operating level of cash flow of listed banks in Botswana.

B. There is no significant relationship between Social media cost and the financing level of cash flow of listed banks in Botswana.

C. There is no significant relationship between Social media cost and the investing level of cash flow of listed banks in Botswana.

\subsubsection{Discussion and Findings}

Social media cost obtained a positive significant relationship with operating cash flow where listed banks in Botswana are concerned (P-value 0.000). The coefficient value revealed 3\%. This means that a $1 \%$ increase in social media cost would result in a 3\% increase in operating cash flow. This result is at par with prior researchers (Unachukwu, 2004; Ikpefan 2013; Tamrakar, 2016 \& Joyce, 2018). This result is at variance with that obtained from the Nigerian sample size and in tandem with the Ghana and South-African segment of this paper.

Additionally, social media cost obtained a positive and significant relationship with the second dependent variable 
financial cash flow (P-value 0.000). The co-efficient variable reveals that a $1 \%$ increase in social media cost would lead to $0.6 \%$ increase in financial cash flow. This result obtained is in line with prior studies (Unachukwu, 2004; Ikpefan 2013; Tamrakar, 2016 \& Joyce, 2018).

Similarly, social media cost and investing cash flow obtained a significant $(\mathrm{P}=0.000)$ and positive relationship. The coefficient result revealed a $.06 \%$ increase in investing cash flow for every $1 \%$ increase in social media cost. This result is in tandem with the statistical evidence obtained from Ghana and South Africa and at variance with prior authors such as (Unachukwu, 2004; Ikpefan 2013; Tamrakar, 2016 \& Joyce, 2018).

\subsection{Test of Hypothesis One $\left(H_{01}\right)$ (Tanzania)}

$\mathrm{H}_{0}$ : There is no significant relationship between Social media cost and the level of cash flow (operating, financing and investing) of listed banks in Tanzania.

Stating hypothesis one in relation to each independent variable we have:

A. There is no significant relationship between Social media cost and the operating level of cash flow of listed banks in Tanzania.

B. There is no significant relationship between Social media cost and the financing level of cash flow of listed banks in Tanzania.

C. There is no significant relationship between Social media cost and the investing level of cash flow of listed banks in Tanzania.

\subsubsection{Discussion and Findings}

Social media cost obtained a negative insignificant relationship with operating cash flow where listed banks in Tanzania are concerned (P-value 0.560 ). The coefficient value revealed $-4 \%$. This means that a $1 \%$ increase in social media cost would result in a $-4 \%$ decrease in operating cash flow. This result is at variance with prior researchers (Unachukwu, 2004; Ikpefan 2013; Tamrakar, 2016 \& Joyce, 2018) study who has recommended social media as a very important public relation tool. This result is at variance with that obtained from the Ghanaian sample size and in tandem with the Nigerian and Tanzanian segment of this result.

In the same vein, social media cost obtained a positive and significant relationship with the second dependent variable financial cash flow (P-value 0.006). The co-efficient variable reveals that a $1 \%$ increase in social media cost would lead to $0.8 \%$ increase in financial cash flow. This result obtained is at par with prior studies (Sianipar, Putri \& Wibisioni (2012); Unachukwu, 2004; Ikpefan 2013; Tamrakar, 2016; Uyiar, Boyar, \& Kuzey 2018 \& Joyce, 2018) but at variance with results obtained in the Nigerian segment of this analysis.

Similarly, social media cost and investing cash flow obtained a significant $(\mathrm{P}=0.726)$ and positive relationship. The coefficient result revealed a $-4 \%$ increase in investing cash flow for every $1 \%$ increase in social media cost. This result in line with prior authors such as (Unachukwu, 2004; Sianipar, Putri \& Wibisioni 2012; Ikpefan 2013; Tamrakar, 2016; Uyiar, Boyar, \& Kuzey 2018 \& Joyce, 2018).

\subsection{Test of Hypothesis One $\left(H_{01}\right)$ (Kenya)}

$\mathrm{H}_{0}$ : There is no significant relationship between Social media cost and the level of cash flow (operating, financing and investing) of listed banks in Kenya.

Stating hypothesis one in relation to each independent variable we have:

A. There is no significant relationship between Social media cost and the operating level of cash flow of listed banks in Kenya.

B. There is no significant relationship between Social media cost and the financing level of cash flow of listed banks in Kenya.

C. There is no significant relationship between Social media cost and the investing level of cash flow of listed banks in Kenya.

4.6.1 Discussion and Findings

Social media cost obtained a positive significant relationship with operating cash flow where listed banks in Kenya are concerned (P-value 0.560 ). The coefficient value revealed $-3 \%$. This means that a $1 \%$ increase in social media cost would result in a 3\% decrease in operating cash flow. This result is at variance with prior researchers (Unachukwu, 2004; Ikpefan 2013; Tamrakar, 2016 \& Joyce, 2018). This result is also at variance with that obtained from the Ghanaian sample size and South-African segment of this article and in line with the Nigerian and Tanzania 
segment of this result.

In the same vein, social media cost obtained a positive and significant relationship with the second dependent variable financial cash flow (P-value 0.000). The co-efficient variable reveals that a $1 \%$ increase in social media cost would lead to $-0.556 \%$ decrease in financial cash flow. This result obtained is at variance with prior studies (Unachukwu, 2004; Ikpefan 2013; Tamrakar, 2016 \& Joyce, 2018) but similar with results obtained in the Nigerian segment of this analysis.

Similarly, social media cost and investing cash flow obtained a significant $(\mathrm{P}=0.086)$ and positive relationship. The coefficient result revealed a $-1.21 \%$ increase in investing cash flow for every $1 \%$ increase in social media cost. This result is at variance with the statistical evidence obtained from Ghana and South Africa and not in line with prior authors such as (Unachukwu, 2004; Ikpefan 2013; Tamrakar, 2016 \& Joyce, 2018).

\subsection{Comparative Analysis Discussion}

The use of social media as a form of advertising has become the order of the day in every sector and listed banks in emerging economies are not an exception. Joyce, (2018) has stated that the use of social media in developed countries have helped increase revenue. Hence this study empirically tested the effect social media cost has on the three levels of cash flows. The table above reveals that for the social media cost and operating cash flow relationship.

For countries such as Nigeria, Tanzania and Kenya. Social media cost has no significant relationship with the operating cash flow. This simply means that advertising has no effect on the organisation's core business which is banking. This implies that customers in listed banks of the above listed countries are not cajoled, inspired or motivated by social media adverts, Radio jingles, brand advertisements and social adverts. This explains why despite many adverts placed by some listed banks in Nigeria, Tanzania and Kenya.

Some of these listed banks are no longer in business today or have had to merge. Examples of such banks include Intercontinental bank, Oceanic bank, Diamond bank, Dubai bank Kenya, Chase bank Kenya, Imperial bank Kenya, Efatha Bank Tanzania, Kagera Bank Tanzania, Covenant Bank Tanzania etc.

Countries such as Ghana, South-Africa and Botswana obtained significant relationships when regressed. This implies that her citizens are motivated by their adverts. Hence social media costs expensed by listed banks in these countries yield more money from their core activity. These results are in line with prior studies such as (Unachukwu, 2004; Ikpefan, 2013; Tamrakar; Joyce, (2018).

A comparison of the results statistically obtained after regressing the second dependent variable (financial cash flow) and the first dependent variable (social media cost) revealed that countries such as Ghana, Botswana, South-Africa, Tanzania and Kenya all attract more cash from their financing cash flow through adverts. This means they attract more investors, sell more stocks etc and this is in line with prior researches that explored the social media concept (Unachukwu, 2004 and Joyce, 2018). Contrastingly, Nigeria is the only country, whose result reflect that the null hypothesis be accepted in this regard. This simply means adverts do not attract or make available more funding options for listed banks in Nigeria.

The comparative analysis for the investing cash flow segment of this result reveal that listed banks in countries such as Nigeria, Ghana, South-Africa and Tanzania make more money from investments and this can be empirically linked to their social media cost figure than listed banks in Botswana and Kenya.

Note: Null hypothesis were accepted because the results were insignificant, this means the

Probability values obtained from the regression were more than 5\%.

Note: Null hypothesis were rejected because the results were significant, this means the Probability values obtained from the regression were less than 5\%.

\section{Conclusion and Recommendation}

Based on the results obtained above, it is evident that social media cost has varying effects on the operating, financing and investing cash flow respectively. This simply means that the use of adverts influences some levels of cash flow in some countries while it has an insignificant impact on some levels of cash flow in others. The study recommends that listed banks in Ghana and South Africa should engage heavily in the use of adverts to publicize their products and services. Other countries utilized as our study's sample size should apply caution in investing in adverts as some of the results obtained failed to establish a statistical relationship.

The policy implication of this study points to the fact that listed banks ought to apply caution in social media costs. This is because not all levels of cash flow respond proportionately to the amount expensed on social media adverts 
and campaigns, as the results obtained differs both on country level and cashflow levels. Listed banks and organisations are therefore admonished to carry out proper empirical analysis before adopting certain corporate strategies.

The tables below summarise results obtained from the regression analysis.

\section{Limitation of the Study}

This study was limited to listed banks of African countries that had published financial statements from year 2013-2018 and also made the emerging economy list of IMF 2019 and BRICS 2019. Further studies should examine other sectors and also explore other corporate strategies relevant in todays' business world as this study narrowed the empirical search to social media cost only.

\section{Contribution to Knowledge}

1. This study provides current empirical evidence on literature relating to social media cost and the effects on the level of cash flow in listed banks in Africa.

2. This study measures a relevant corporate strategy in todays' business world such as social media costs. Prior studies were limited to firm size, financial leverage etc.

3. This study contributes to knowledge by increasing the scope of the study, as emerging economies in Africa 2019 have been included in the sample size.

4. This study measures the effect social media costs has on the three levels of cash flow. Prior studies measured other corporate strategies and were limited to only the operating level of cash flow, while other studies employed the use of profitability values.

5. The model developed for this study serves as one of the contributions to knowledge as it includes social media costs and control variables such as financial leverage and board size and the three levels of cash flows.

6. Prior studies employed the use of the survey-research design, while this study employed the expo-facto research, utilizing audited figures from the financial statements of listed banks in emerging economies in Africa.

\section{References}

ACCA. (2018). Auditing and Assurance (F8) (pp. 1-97). Ivy League Associates.

BRICS. (2019). Retrieved from http://worldpopulationreview.com/countries/bric-countries/

Chukwu, N., Asaolu, T. O., Uwuigbe, O. R., Uwuigbe, U., Umukoro, O. E., Nassar, L., \& Alabi, O. (2019). The impact of basic forensic accounting skills on financial reporting credibility among listed firms in Nigeria. IOP Conference on Earth and Environmental Sciences, 331(1). https://doi.org/10.1088/1755-1315/331/1/012041

Ciao, X., Guo, X., Vogel, D., \& Zhang, X. (2016). Exploring the influence of social media on employee work performance. Internet Research, 26(2), 529-545.

Hilgen, M. (2015). The determinants of cash holdings: Evidence from German listed firms. University of Twente, School of Management and Governance.

Ikpefan, O. (2013). The impact of marketing of financial services in the Nigerian banking industry. Journal of Business Administration and Management Sciences Research, 2(6). Retrieved from http://www.apexjournal.org

IMF. (2019). Retrieved from https://www.africa-business.com/features/africa-emerging-business.html

Joyce, L. (2018). Social media strategy-banking. Retrieved from https://thefinancialbrand.com/68173/social-media-trends-strategy-banking

Klautzsch, E. A. (2017). Social media performance management leveraging social Interactions along the customer journey (pp. 1-139). University of St. Gallen, School of Management, Economics, Law, Social Sciences and International Affairs.

Kumar, V., \& Devi, R. (2014). Social media in financial services - a theoretical perspective. Symbiosis Institute of Management Studies Annual Research Conference (SIMSARC13). Procedia Economics and Finance, 11. https://doi.org/10.1016/S2212-5671(14)00198-1

Merino, M., Srinivasan, R., \& Srivastava, R. (2006). Advertising, research and development and variability of cash flow and intangible firm value.

Ojeka, S., Adegboye, A., Adegboye, K., Umukoro, O., Dahunsi, O., \& Ozordi, E (2019). Corruption Perception, 
Institutional quality and Performance of listed companies in Nigeria. Heliyon Journal, 5(10). https://doi.org/10.1016/j.heliyon.2019.e02569

Okari, A. (2016). Social media usage and financial performance in micro finance institutions in Kenya. University of Nairobi.

Osagie, O. (2016). Firm size, age and operating cash flow: empirical standpoint on Nigerian banking sector. International Journal of Advanced Academic Research Social \& Management Sciences, 2(8), 95-103.

Pilcher, J. (2018). Marketing trends and banking strategies. Retrieved from https://thefinancialbrand.com/69067/2018-marketing-trends-banking-strategies/

Schniederjans, D., Cao, E., \& Schniederjans, M. (2013). Enhancing financial performance with social media: An impression management perspective. Decision Support Systems, 55(4), 911-918. https://doi.org/10.1016/j.dss.2012.12.027

Sianipar, M., Putri, C., \& Wibisono, D. (2012). Social media and performance evaluation: Moving towards a new approach. The 3rd International Conference on Technology and Operations Management "Sustaining Competitiveness through Green Technology Management” (pp. 715-721). Bandung, Indonesia.

Tamrakar, C. (2016). Essays on social media and firm financial performance. Doctor of Philosophy thesis, University of Iowa. Retrieved from https://ir.uiowa.edu/etd/2153

Tutor. (2018, October). How to read a cash flow statement. Retrieved from http://www.graduatetutor.com/accounting-tutors/how-to-read-a-cash-flow-statement/

Umukoro, O. E., Eluyela, D. F., Ozordi, E., Inua, O. I., \& Balogun, S. B. (2020). Nollywood Accounting and Financial Performance: evidence from Nigerian Cinemas. International Journal of Financial Research, 11(2), 271-280. https://doi.org/10.5430/ijfr.v11n2p271

Umukoro, O., Uwuigbe, O., Uwuigbe, U., Adegboye, A., Ajetunmobi, O., \& Nwaze, C. (2019). Board expertise and sustainability reporting in listed banks in Nigeria. IOP Conference Series: Earth and Environmental Science, (331). https://doi.org/10.1088/1755-1315/331/1/012048

Unachukwu, C. (2004). Effectiveness of strategic marketing in Nigerian banks: a study of some selected banks. Department of marketing Faculty of business administration. University of Nigeria.

Uyiar, A., Boyar, E., \& Kuzey, C. (2018). Does social media enhance firm value? Evidence from Turkish firms using three social media metrics. The Electronic Journal of Information Systems Evaluation, 21(8), 131-142.

World Bank. (2018, April 19). Financial inclusion on the rise but gaps remain global findex database shows. Retrieved

from https://www.worldbank.org/en/news/press-release/2018/04/19/financial-inclusion-on-the-rise-but-gaps-remainglobal-findex-database-shows 